\title{
Diseminasi Hasil Riset Antimikroba Alami Berbasis Pemanfaatan Limbah Kulit Buah Menjadi Soft Soap Herbal di Sentra Industri Keripik Pisang Lampung
}

\author{
Dewi Sartika \\ Universitas Lampung
}

\author{
Susilawati \\ Universitas Lampung
}

\author{
Neti Yuliana \\ Universitas Lampung
}

\author{
Rusita \\ Universitas Lampung
}

\begin{abstract}
The Center of Chips Home Industry (IRT), located at Jalan Pagar Alam, is one of the most popular culinary tourism centers. This IRT produces waste discharges such as fruit skins, leaves, fruit stalks, humps that have not been adequately managed, and even disposal is still carried out at the edge of a river body. The IRT waste can potentially be made of highvalue natural anti-microbial products such as diversified products in the form of soap. The purpose of this service activity was to carry out the transfer of research technology and solving the problem of waste from the Home Industry Center (IRT) of chips as a service partner. Technology transfer of research results in the form of (1) waste treatment technology to become natural anti-microbial, (2) diversified natural anti-microbial product technology, and (3) technology for processing soap products. The dedication methods were done by lecturing and discussing the dissemination of research results and assisting the processing of waste into natural anti-microbial products such as soap. The needs of partners in information technology were as follows: making solid herbal soap $26 \%$, followed by liquid soap $24 \%$, hand sanitizer $17 \%$, natural antimicrobial 12\%, making feed 10\%, and compost and liquid fertilizer $8 \%$. Dissemination activities showed an increase in knowledge and understanding of the material after the devotion activities, namely the use of waste (40\%) and making soft soap (80\%).
\end{abstract}

Keywords: Food Preservatives; Hand sanitizer; Natural anti-microbial; Soap

\section{Abstrak}

Sentra Industri Rumah Tangga (IRT) Keripik yang beralamat di Jalan Pagar Alam merupakan salah satu sentra wisata kuliner yang cukup populer. IRT keripik ini menghasilkan limbah buangan seperti kulit buah, daun, tangkai buah, bonggol yang belum dikelola dengan baik, dan bahkan pembuangan yang masih dilakukan di tepi badan sungai. Limbah buangan IRT keripik tersebut sangat berpotensi untuk dibuat antimikroba alami yang bernilai jual tinggi, misalnya produk diversifikasi berupa sabun. Tujuan pengabdian ini adalah melakukan transfer teknologi hasil riset dan memecahkan masalah limbah buangan sentra IRT Keripik sebagai mitra pengabdian. Transfer teknologi hasil riset berupa: (1) teknologi pengolahan limbah buangan menjadi antimikroba alami; (2) teknologi diversifikasi produk antimikroba alami; dan (3) teknologi pengolahan produk sabun. Metode pengabdian dilakukan dengan cara ceramah dan diskusi hasil riset serta pendampingan pengolahan limbah buangan menjadi produk antimikroba alami berupa sabun. Kebutuhan mitra pada informasi teknologi adalah sebagai berikut: pembuatan sabun padat herbal $26 \%$, diikuti sabun cair $24 \%$, hand sanitizer $17 \%$, antimikroba alami $12 \%$, pembuatan pakan $10 \%$, serta pembuatan kompos dan pupuk cair $8 \%$. Kegiatan diseminasi menunjukkan bahwa terjadi peningkatan pengetahuan dan pemahaman materi setelah kegiatan pengabdian, yaitu tentang pemanfaatan limbah buangan (40\%) dan pembuatan soft soap (80\%).

Kata kunci: Antimikroba alami; Hand sanitizer; Pengawet pangan; Sabun

\section{Pendahuluan}

Kawasan Sentra Industri Keripik adalah sentra oleh-oleh makanan khas Lampung. Kawasan tersebut terletak di jantung Kota Bandar Lampung, tepatnya di Kelurahan Segalamider, Kecamatan Kedaton, dan dapat dituju melalui Jl. Teuku Umar atau Jl. Imam Bonjol. Masyarakat Kota Bandar Lampung lebih suka menyebut kawasan tersebut dengan sebutan Keripik Gang PU. 
Kawasan tersebut dapat ditempuh dari Terminal Rajabasa atau Stasiun Kereta Api Tanjungkarang dalam waktu kurang lebih 15 menit.

Jenis keripik yang ditawarkan antara lain keripik pisang, nangka, dan singkong. Cita rasa keripik yang dijual di pasar swalayan yaitu gurih, asin manis, keju, dan coklat, dengan harga yang sangat terjangkau, yaitu berkisar Rp28.000-Rp45.000/kg. Prospek di kawasan ini sangat baik karena pembeli yang datang tidak hanya dari seputaran Kota Bandar Lampung saja melainkan juga dari Metro, Gunung Sugih, bahkan dari luar Pulau Sumatera. Kawasan ini dirintis sejak beberapa tahun yang lalu. Rasa industri didapat dari Negerisakti, Pringsewu, Wayhalim, dan Rajabasa.

Industri keripik pisang ini ternyata menghasilkan limbah buangan berupa kulit atau bonggol yang biasanya dibuang pada aliran sungai di belakang kawasan ini. Padahal, pisang beserta kulitnya masih memiliki potensi untuk dikembangkan dalam bentuk lain. Bahan-bahan buangan pertanian berpotensi untuk dimanfaatkan kembali, antara lain sebagai sumber asamasam organik (Undadraja \& Sartika, 2017) dan sumber antimikroba alami (Sartika, Herdiana, dkk., 2017; Sartika, Suharyono, dkk., 2017; Sartika, Syarifah, dkk., 2017). Kandungan antioksidan yang tinggi pada pisang berpotensi digunakan sebagai pengawet pangan (Sartika dkk., 2017). Pengawet pangan dapat menurunkan cemaran mikrobia pangan (Sartika, 2018b). Menurut Sartika dkk. (2017), kulit pisang berpotensi sebagai antimikroba alami; begitu juga singkong konsumsi (Iswandari dkk., 2016); singkong karet racun (Hartari dkk., 2017), kulit buah naga (Sartika dkk., 2017), dan tomat cherry (Sartika dkk., 2017). Selain tumbuhan, ternyata bacteriophage pun berpotensi dijadikan sebagai antimikroba alami (Sartika dkk., 2017; Sartika, 2018a), bahkan, aman ketika diuji coba in-vivo pada tikus sprague dawley (Sartika dkk., 2012). Antimikroba alami bisa dimanfaatkan untuk bahan baku pembuatan hand sanitizer dan produk sabun, misalnya soft soap.

Hand sanitizer dan produk sabun yg berbahan antimikroba alami sangatlah aman (safe) dibandingkan dengan produk di pasaran saat ini karena menggunakan bahan baku sintetis. Transfer teknologi/hasil riset ini diharapkan dapat memecahkan masalah limbah buangan dan meningkatkan pendapatan pengusaha keripik di Sentra Industri Keripik. Lokasi Industri Rumah Tangga (IRT) keripik dan lokasi pembuangan limbah buangan industri keripik di pinggir badan sungai tersaji pada Gambar 1.

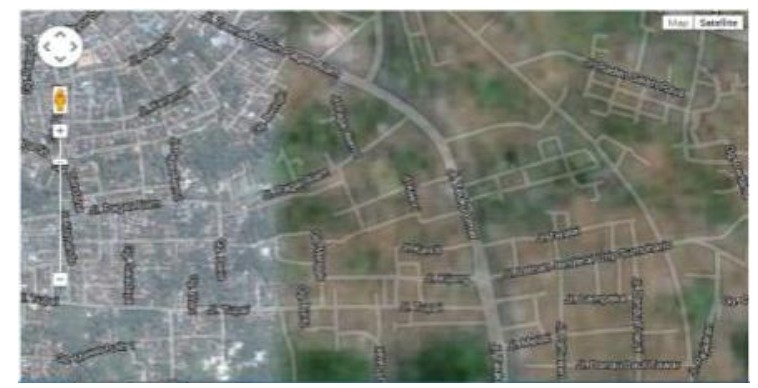

(a)

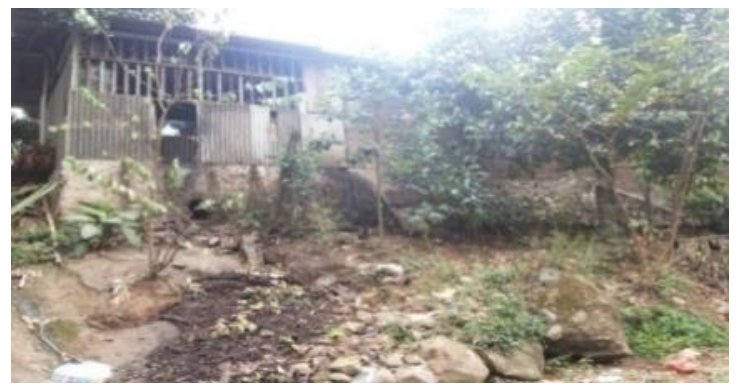

(b)

Gambar 1. (a) Lokasi IRT keripik (Sumber: Google Maps) dan (b) Lokasi pembuangan limbah buangan industri keripik di pinggir badan sungai (Sumber: dokumentasi pribadi)

Untuk mewujudkan program tersebut, Tim Program Hi-Link, Universitas Lampung (Unila) dari Program Studi Teknologi Hasil Pertanian (THP) dan Program Studi Teknologi Industri Pertanian (TIP) mencoba menjadi fasilitator untuk memecahkan masalah ini dengan cara diseminasi hasil riset. Pada program pengabdian ini, yang menjadi mitra adalah IRT keripik ZomZom dan Dua Dara. Pengabdian ini dilakukan dengan kuesioner tahap awal untuk mengetahui pengetahuan mitra terhadap pengetahuan yang akan ditransfer. 


\subsection{Permasalahan Mitra}

Sentra IRT keripik menghasilkan limbah buangan yaitu kulit, bonggol, dan tangkai buah. Limbah buangan ini dibuang di pinggir badan sungai tanpa pengolahan. Padahal, limbah buangan keripik masih bisa diolah menjadi produk yang memiliki nilai jual, misalnya menjadi kompos dan sumber antimikroba alami. Kulit buah memiliki potensi sumber antimikroba alami, misalnya kulit buah pisang (Sartika dkk., 2017); kulit buah naga (Sartika dkk., 2017); buah cherry (Sartika dkk., 2017); kulit singkong (Hartari dkk., 2017); atau daun singkong (Undadraja \& Sartika, 2017).

Kulit buah pisang, naga, dan singkong berpotensi dibuat menjadi antimikroba alami karena mengandung tanin, phenol, komponen karboksilat, dan asam organik (Sartika dkk., 2017). Produk luaran antimikroba alami bisa berupa hand sanitizer, soft soap, dan pengawet pangan kantong. Ketiga produk tersebut di pasaran menggunakan antibakteri/antimikroba sintetis yang berbahaya bila dipakai terus-menerus sehingga alternatif ini berpotensi menggantikan produk yang ada di pasaran.

Permasalahan mitra adalah minimnya pengetahuan pengolahan limbah dan diversifikasi produk sehingga perlu: (1) transfer teknologi pengolahan limbah buangan menjadi antimikroba alami; (2) transfer teknologi diversifikasi produk antimikroba alami; dan (3) transfer teknologi pengolahan produk soft soap. Diseminasi hasil riset antimikroba alami ini diharapkan selain dapat menyelesaikan permasalahan limbah buangan juga dapat meningkatkan pendapatan pengusaha keripik.

\subsection{Tujuan dan Manfaat Kegiatan}

Tujuan kegiatan pengabdian ini yaitu: (1) Meningkatkan pengetahuan pengelola IRT keripik mengenai teknologi pengolahan limbah buangan menjadi antimikroba alami dan skill dalam membuat produk antimikroba alami dengan survei awal menggunakan kuesioner; (2) Meningkatkan pengetahuan pengelola IRT keripik mengenai teknologi diversifikasi produk antimikroba alami dan skill dalam mendiversifikasi produk antimikroba alami; (3) Meningkatkan pengetahuan pengelola IRT keripik mengenai teknologi pengolahan produk soft soap dan skill dalam membuat produk soft soap; serta (4) Meningkatkan pendapatan pengelola IRT keripik.

Adapun manfaat kegiatan pengabdian terhadap pengelola IRT dan masyarakat yakni: (1) Pengelola IRT keripik menerima transfer teknologi pengolahan limbah buangan menjadi antimikroba alami dan mampu membuat produk antimikroba alami; (2) Pengelola IRT keripik menerima transfer teknologi diversifikasi produk antimikroba alami dan mampu mendiversifikasi produk antimikroba alami; serta (3) Pengelola IRT keripik menerima transfer teknologi pengolahan produk soft soap dan mampu membuat produk soft soap.

\section{Metode Pelaksanaan}

\subsection{Metode dan Tahapan dalam Penerapan Hasil Riset ke Masyarakat}

Metode pelaksanaan kegiatan pengabdian ini yakni ceramah dan diskusi diseminasi hasil riset serta pendampingan pengolahan limbah buangan menjadi produk antimikroba alami berupa soft soap. Penyampaian materi kegiatan pengabdian masyarakat akan dilaksanakan dengan metode ceramah. Kemudian, dilakukan diskusi (tanya jawab) yang akan memberikan kesempatan kepada peserta untuk proses pemahaman materi atau penyampaian gagasan dan permasalahan terkait cara produksi yang baik dan pemanfaatan fage pada industri pangan.

Penerapan hasil riset yang akan disampaikan pada kegiatan pengabdian masyarakat dalam ceramah dan diskusi meliputi: (1) Teknik pengolahan limbah buangan; (2) Teknik pengolahan diversifikasi limbah buangan; (3) Teknik pengolahan antimikroba alami; serta (4) Teknik pengolahan limbah buangan soft soap. 
Adapun teknik pengumpulan dan analisis data pengabdian dilakukan dengan cara: (1) Evaluasi awal, dilakukan pada awal kegiatan pengabdian dengan cara memberikan kuesioner; dan (2) Evaluasi akhir, dilakukan pada akhir kegiatan pengabdian masyarakat dengan memberikan tes akhir yang berupa kuesioner dengan pertanyaan yang sama dengan tes awal. Kemudian, data diolah. Hasilnya dibandingkan dengan hasil evaluasi tes awal (pertama) untuk melihat seberapa jauh peningkatan pemahaman peserta sosialisasi.

\subsection{Deskripsi Hasil Riset/Teknologi yang Akan Didesiminasi ke Masyarakat}

Deskripsi hasil riset/teknologi yang akan didesiminasi ke masyarakat disajikan pada Tabel 1.

Tabel 1. Deskripsi hasil riset/teknologi yang akan didesiminasi ke masyarakat

\begin{tabular}{ll}
\hline Topik & Deskripsi Hasil Riset/Teknologi yang Akan Didiseminasi \\
\hline $\begin{array}{l}\text { Pengolahan limbah } \\
\text { buangan }\end{array}$ & $\begin{array}{l}\text { Pengolahan limbah organik pengolahan keripik menjadi kompos } \\
\text { (riset Sartika tahun 2015) }\end{array}$ \\
\hline Antimikroba alami & $\begin{array}{l}\text { Buangan limbah mitra berupa kulit buah berpotensi untuk menjadi } \\
\text { antimikroba alami yang mempunyai nilai jual tinggi. Menurut } \\
\text { penelitian Sartika, sumber antimikroba alami didapat dari: kulit buah } \\
\text { naga (Sartika dkk., 2017) dan kulit nenas (Sartika dkk., 2017), kulit } \\
\text { pisang dan jantung pisang (Sartika dkk., 2017), kulit singkong } \\
\text { (Sartika \& Sutikno, 2016), kulit jeruk (Sartika, 2017), mengkudu dan } \\
\text { singkong karet racun (Sartika, 2016), serta bacteriophage (Sartika, } \\
\text { 2018). }\end{array}$ \\
\hline $\begin{array}{l}\text { Pengolahan, soft soap, } \\
\text { pengawet pangan } \\
\text { kantong }\end{array}$ & $\begin{array}{l}\text { Menurut Sartika dkk. (2017), diversifikasi produk antimikroba alami } \\
\text { dapat berupa soft soap. }\end{array}$ \\
\hline
\end{tabular}

\subsection{Prosedur Kerja untuk Mendukung Realisasi Metode yang Ditawarkan}

Langkah-langkah kerja untuk mendukung realisasi metode yang ditawarkan meliputi:

a. Pembuatan Serbuk Antimikroba Alami

Cara pembuatan serbuk disajikan pada Gambar 2.

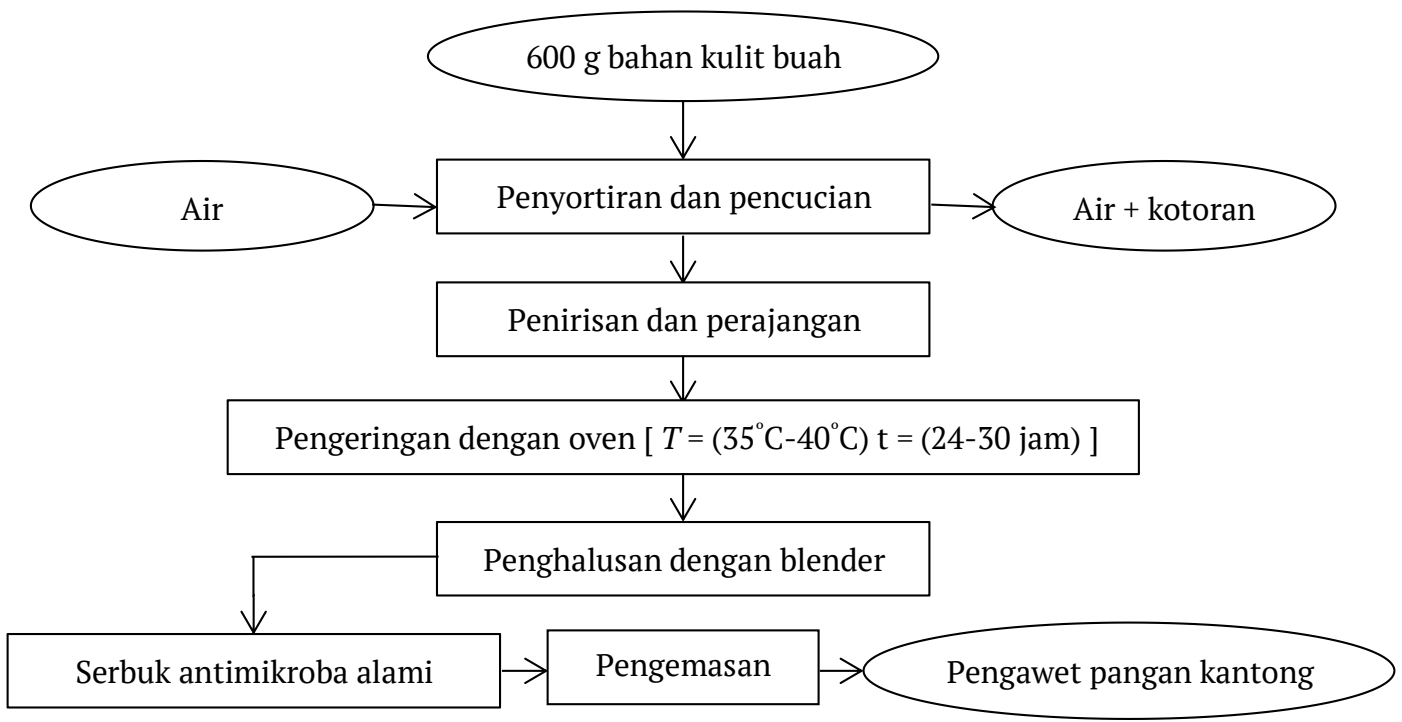

Gambar 2. Diagram alir pembuatan serbuk antimikroba alami dan pengawet pangan kantong 
Limbah kulit disiapkan secara terpisah masing-masing $600 \mathrm{~g}$ yang telah disortir lalu dicuci. Daun ditiriskan dan dirajang. Setelah itu, daun dikeringkan menggunakan oven $\left(\mathrm{T}=35^{\circ} \mathrm{C}-\right.$ $40^{\circ} \mathrm{C}$ ) selama 24-30 jam (Sartika dkk., 2017 modifikasi dari Sitap dkk., 2015). Daun yang telah kering dihaluskan dengan blender hingga berbentuk serbuk.

\section{b. Pembuatan Soft Soap}

Pembuatan hand sanitizer sebagai berikut.

1) Pencampuran minyak jarak, minyak zaitun, dan minyak kelapa lalu diaduk perlahan hingga homogen.

2) Penambahan $300 \mathrm{ml}$ larutan $\mathrm{KOH} 10 \%$ sedikit demi sedikit ke dalam campuran minyak pada suhu $60-70^{\circ} \mathrm{C}$ hingga terbentuk pasta.

3) Penambahan asam stearat cair (sudah dilarutkan) dan pengadukan hingga homogen.

4) Penambahan BHT dan HPMC yang telah dikembangkan dalam akuades panas, dimasukkan ke dalam campuran.

5) Penambahan gliserin dan ekstrak antimikroba alami lalu diaduk hingga homogen.

6) Penambahan akuades $100 \mathrm{ml}$ (sesuai konsentrasi yang diinginkan) dan diaduk hingga homogen.

7) Pengemasan produk soft soap dari bahan antimikroba alami.

8) Penambahan ekstrak antimikroba alami pada poin 5 bisa berasal dari bahan baku kulit buah yang berpotensi sebagai herbal. Menurut Sartika dkk. (2017), kulit buah yang berpotensi sebagai antimikroba alami/herbal ialah kulit buah naga, kulit pisang, kulit jeruk, termasuk kulit singkong.

\subsection{Pihak-Pihak yang Terlibat dalam Kegiatan Diseminasi Hasil Riset kepada Masyarakat}

Pihak-pihak yang terlibat dalam kegiatan diseminasi hasil riset kepada masyarakat yaitu: (1) Tim Pengabdian THP, Unila; (2) Ketua Jurusan THP; (3) Lab Mikrobiologi THP, Unila; (4) Lab Pengolahan THP, Unila; serta (4) Mitra.

\subsection{Partisipasi Mitra}

Partisipasi mitra dalam kegiatan ini yakni: (1) menyediakan lokasi diseminasi; (2) menyediakan bahan baku antimikroba alami; dan (3) menyediakan instalasi listrik saat diseminasi untuk mengoperasikan alat.

\subsection{Evaluasi Pelaksanaan Program dan Keberlanjutan Program}

Evaluasi pelaksanaan pengabdian dilaksanakan dengan cara:

a. evaluasi awal, dilakukan pada awal kegiatan pengabdian dengan cara memberikan kuesioner di awal pengabdian; dan

b. evaluasi akhir, dilakukan pada akhir kegiatan pengabdian masyarakat dengan memberikan tes akhir yang berupa kuesioner dengan pertanyaan yang sama dengan tes awal. Data kemudian diolah dan hasilnya dibandingkan dengan hasil evaluasi awal tes pertama untuk melihat seberapa jauh peningkatan pemahaman peserta sosialisasi. Analisis dan pengolahan data dilakukan secara deskriptif.

Keberlanjutan program dilakukan dengan cara: (1) tetap memberikan pendampingan pascakegiatan pengabdian; (2) akan dibuat ikon produk dengan logo Binaan Unila yang diharapkan bisa dibeli mahasiswa atau dosen unila, bahkan masyarakat; dan (3) dijadikan oleholeh khas THP (Lampung). 


\section{Hasil dan Pembahasan}

\subsection{Kegiatan 1}

Kegiatan 1 adalah survei kebutuhan mitra yang urgen yang dilakukan oleh tim pengabdi Unila (Dewi Sartika, Susilawati, dan Neti Yuliana). Tim melakukan wawancara tentang: (1) pengelolaan limbah di kawasan industri rumah tangga keripik; (2) pembuatan serbuk antimikroba alami; (3) soft soap; (4) pembuatan hand sanitizer; (5) pembuatan kemasan serbuk antimikroba alami pangan; dan (6) pembuatan keripik. Hasil menunjukkan bahwa persentase keinginan mitra berdasarkan survei yang dilakukan tersaji pada Gambar 3.

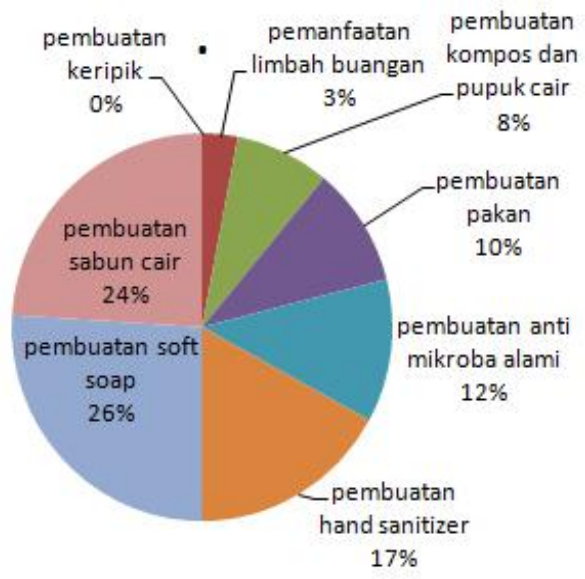

Gambar 3. Persentase keinginantahuan mitra untuk mengembangkan produk samping yang bernilai jual

Ternyata, mitra menginginkan info pembuatan sabun padat herbal $26 \%$, diikuti sabun cair $24 \%$, hand sanitizer $17 \%$, anti mikroba alami $12 \%$, pembuatan pakan $10 \%$, pembuatan kompos dan pupuk cair $8 \%$. Uniknya, mitra tidak meminta info atau sosialisasi tentang keripik, kemungkinan sudah banyak info tentang keripik.

\subsection{Kegiatan 2}

Berdasarkan persentase kebutuhan mitra, dilakukan: (1) pembuatan keripik; (2) pemanfaatan limbah buangan; (3) pembuatan kompos dan pupuk cair; (4) pembuatan pakan; (5) pembuatan antimikroba alami; (6) pembuatan hand sanitizer herbal; (7) pembuatan soft soap herbal; dan (8) pembuatan sabun cair herbal. Terlihat persentase terbesar adalah pada poin 2-8, diperlukan mesin penghancur limbah buah pada proses pembuatan keripik sehingga tim memutuskan untuk melakukan pemberian mesin penghancur atau grinder (Gambar 4).

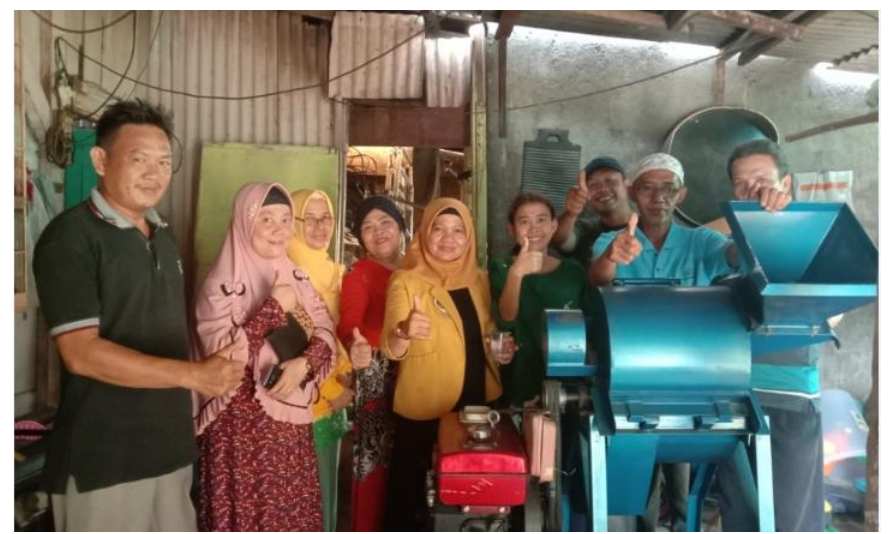

Gambar 4. Alat penghancur buangan organik industri keripik 


\subsection{Kegiatan 3}

Pembuatan soft soap herbal, dilakukan di laboratorium dan disosialisasikan kepada masyarakat dengan cara demonstrasi dan praktik (Gambar 5). Di akhir kegiatan 3, dilakukan pembuatan klip video kegiatan pembuatan soft soap herbal.
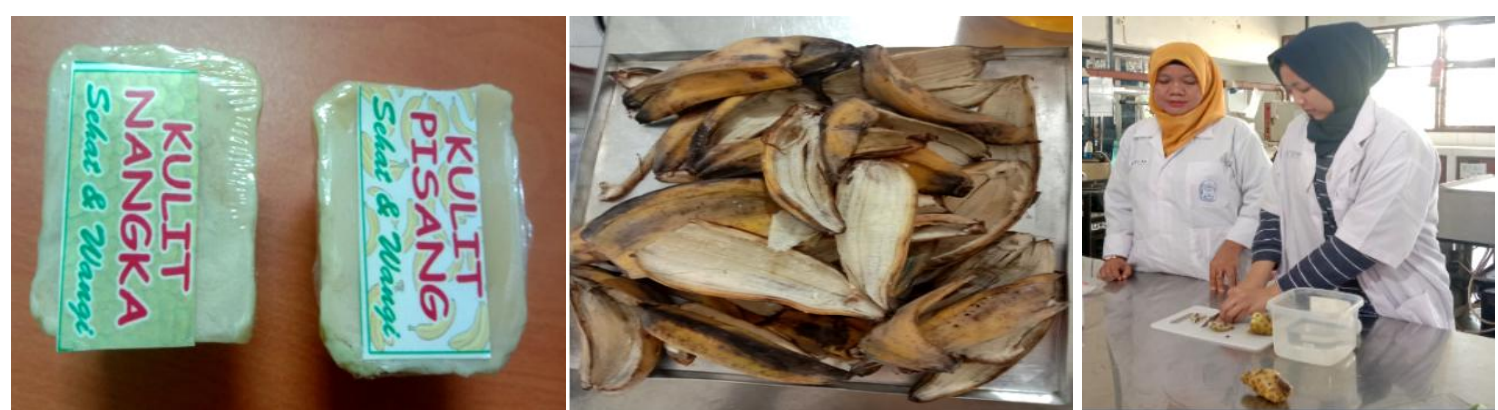

Gambar 5. Pembuatan soft soap herbal

Setelah dilakukan sosialisasi dan praktik pembuatan soft soap terhadap mitra, mitra dapat memanfaatkan limbah industri keripik pisangnya dengan membuat sabun. Soft soap yang telah dibuat oleh mitra selanjutnya dapat dijadikan produk tambahan yang dapat ditawarkan kepada konsumen. Dengan begitu, harapannya, pendapatan mitra dapat bertambah dengan adanya soft soap hasil kulit limbah industrinya.

\subsection{Kegiatan 4}

Pembuatan dan penyelesaian pembuatan klip video kegiatan dengan setting di laboratorium dan saat melakukan sosialisasi dengan masyarakat (Gambar 6). Pembuatan klip video di-finishing oleh tim multimedia.

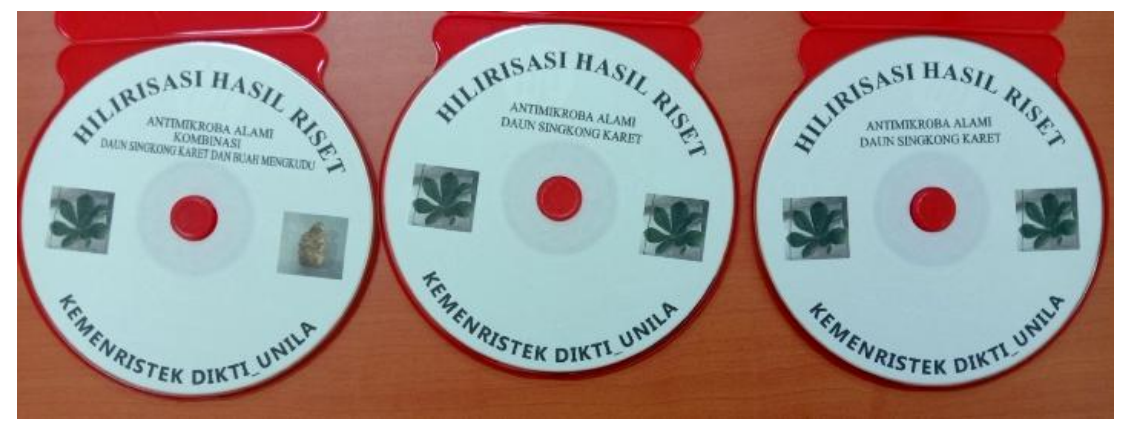

Gambar 6. Pembuatan klip video di-finishing oleh tim multimedia

\subsection{Ketercapaian Tujuan Berdasarkan Kuesioner}

Tim melakukan sosialisasi berupa ceramah dan demonstrasi materi-materi, antara lain pembuatan: (1) serbuk antimikroba alami; (2) soft soap; (3) hand sanitizer; dan (4) kemasan serbuk antimikroba alami. Hasil pembacaan angket berdasarkan pemahaman mitra terhadap materi yang telah disampaikan disajikan pada Tabel 2.

Berdasarkan hasi desiminasi yang telah dilakukan terhadap mitra yang terlibat maka diperoleh peningkatan pengetahuan mitra terhadap penguasaan keterampilan dalam mengolah limbah indutri keripik menjadi bahan yang memiliki nilai jual. Selanjutnya, mitra dapat mengembangkan lebih lanjut sehingga produk hasil olahan limbah industri keripik dapat bernilai ekonomi. 
Tabel 2. Peningkatan persentase pemahaman dan penguasaan keterampilan terhadap materi sosialisasi yang disampaikan

\begin{tabular}{clccc}
\hline \multirow{2}{*}{ No. } & \multirow{2}{*}{ Pengetahuan } & \multicolumn{3}{c}{ Persentase Pemahaman (\%) } \\
\cline { 2 - 5 } & & Awal & Akhir & Kenaikan \\
\hline 1 & Pemanfaatan limbah buangan & 10 & 50 & 40 \\
2 & Pembuatan kompos dan pupuk cair & 20 & 70 & 50 \\
3 & Pembuatan pakan & 20 & 60 & 40 \\
4 & Pembuatan antimikroba alami & 0 & 70 & 70 \\
5 & Pembuatan hand sanitizer & 0 & 60 & 60 \\
6 & Pembuatan soft soap & 0 & 80 & 80 \\
7 & Pembuatan sabun cair & 0 & 70 & 70 \\
\hline
\end{tabular}

\section{Kesimpulan}

Kesimpulan dari kegiatan ini ialah:

a. Kebutuhan mitra industri rumah tangga keripik dalam mengolah produk limbah atau buangan menjadi produk yang mempunyai nilai jual adalah info pembuatan sabun padat herbal $26 \%$, diikuti sabun cair $24 \%$, hand sanitizer $17 \%$, antimikroba alami $12 \%$, pembuatan pakan $10 \%$, serta pembuatan kompos dan pupuk cair $8 \%$.

b. Persentase peningkatan pengetahuan dan pemahaman materi setelah kegiatan pengabdian yaitu pemanfaatan limbah buangan sebesar $40 \%$, pembuatan anti mikroba alami $40 \%$, dan pembuatan soft soap $80 \%$. Sehingga, diharapkan masyarakat dapat memproduksi sabun padat dan mampu menjualnya.

\section{Ucapan Terima Kasih}

Ucapan terima kasih Tim Pengabdian THP ditujukan kepada Unila yang telah mendanai program ini melalui Hibah BLU Diseminasi Hasil Riset.

\section{Daftar Pustaka}

Hartari, W. R., Sartika, D., \& Suharyono, A. (2017). Using Ceara Rubber as Natural Anti-Microbe in Reducing Contamination of Staphylococcus aureus, Salmonella sp., Vibrio sp. And Escherichia coli in Mackerel Tuna Fish (Euthynnus affinis). Proceeding International Conference On Cassava, 54-59.

Iswandari, Sartika, D., \& Astuti, S. (2016). Aktivitas Anti mikroba Alami Singkong (manihot utilisima) [Laporan Penelitian]. Universitas Lampung.

Sartika, D. (2012). Efektifitas Lisis dan Keamanan Phage Fr38 [Disertasi]. Bogor Agricultural University.

Sartika, D. (2018a). Bacteriophage (Fage) Sebagai Biokontrol Alami Pada pangan dan Lingkungan Pada Pangan. Penerbit Graha Ilmu.

Sartika, D. (2018b). Cemaran Bakteri Patogen Pada Pangan (Uji Kualitatif dan Kuantitatif). Penerbit Graha Ilmu.

Sartika, D., Budiarti, S., \& Mirnawati. (2012). Safety The Effect Of Indigenous Salmonella P38 Phage (Phage Fr38) On Sprague Dawley Strain Rat. HAYATI Journal of Biosciences, 19(3), 131-136.

Sartika, D., Budiarti, S., \& Sudarwanto, M. (2012). Bacteriophage (Phage) FR38 Treatment on Sprague Dawley Rat Inferred from Blood Parameters and Organ Systems. HAYATI Journal of Biosciences, 19(3), 131-136. 
Sartika, D., Herdiana, N., \& Kusuma, S. N. (2017). Kajian Daya Hambat Ekstrak Kulit Dan Jantung Pisang Muli (Musa Acuminata) Sebagai Antimikroba Alami Dalam Menurunkan Cemaran Echerichia Coli Pada Daging Ayam (Gallus Domesticus) [Laporan Penelitian]. Universitas Lampung.

Sartika, D., Suharyono, A., \& Putri, F. D. (2017). Study Control Of Salmonella Sp. Contamination On White Shrimp (Litopenaeus Vannamei) Using Natural Antimicrobial From Extract Of Cherry Tomatoes Fruits (Lycopersicum Cerasiformae Mill.). Proceeding Of Isae International Seminar: Strengthening Food and Feed Security and Energy Sustainability to Enhance Competitiveness, 531-538.

Sartika, D., \& Sutikno. (2016). Aktivitas Antimikroba Alami dari Kulit Nenas dan Kulit Jeruk [Laporan Penelitian]. Universitas Lampung.

Sartika, D., Syarifah, R. M., \& Sutikno. (2017). The Profile Of Red Dragon Fruit Peel Extract As A Natural Antimicrobials In Reducing E. Coli. Proceeding Of Isae International Seminar: Strengthening Food and Feed Security and Energy Sustainability to Enhance Competitiveness, $565-568$.

Undadraja, B., \& Sartika, D. (2017). Identifying Chemical Compound in Ceara Rubber Skin Which Is Potential To Be Natural Anti-Microbe By Using Gas Chromatography-Mass Spectrometry (GCMS). Proceeding International Conference On Cassava, 24-27. 


\section{Afiliasi:}

Dewi Sartika ${ }^{(*)}$, Susilawati, Neti Yuliana, Rusita

Universitas Lampung

Jl. Prof. Dr. Sumantri Brojonegoro No. 1, Bandar Lampung, Indonesia, 35145

E-mail : dewikincai@yahoo.com ${ }^{(*)}$,susilawatithp@unila.ac.id,neti.yuliana@fp.unila.ac.id 